\title{
The Effects of Modified Atmosphere Packaging on the Microbiological Properties of Fresh Common Carp (Cyprinus carpio L.)
}

\author{
Katarína Hudecová, Hana Buchtová, Iva Steinhauserová \\ Department of Meat Hygiene and Technology, Faculty of Veterinary Hygiene and Ecology, University of \\ Veterinary and Pharmaceutical Sciences Brno, Czech Republic
}

Received March 5, 2009

Accepted December 3, 2009

\begin{abstract}
The aim of this study was to compare the growth rate of total viable counts (TVC), psychrotrophic viable counts (PVC), coliform bacteria and E. coli in portions of fresh common carp (Cyprinus carpio L.) under two different modified atmosphere packaging (experimental MAP1: $70 \% \mathrm{~N}_{2} / 30 \% \mathrm{CO}_{2}$ experimental MAP2: $80 \% \mathrm{O}_{2} / 20 \% \mathrm{CO}_{2}$ ) and air (control samples) stored at $+4 \pm 0.5^{\circ} \mathrm{C}$, and to determine their shelf life. The presence of pathogens (Salmonella spp. and Listeria monocytogenes) was also surveyed in this study. A total of 360 portions from 90 common carp were examined. Laboratory analyses were performed on storage day 0 (production day) and days 3, 7 and 10. As compared to air packaging, the numbers of TVC and PVC were significantly lower $(p<0.001)$ in both modified atmosphere packaging (MAP) on storage days 7 and 10; coliform bacteria were significantly lower only on day 7. E. coli counts in fresh carp during storage were generally low, showing levels of $<1 \log \mathrm{cfu} / \mathrm{g}$. Salmonella spp. and Listeria monocytogenes were not detected in any of the examined samples. All the strains of Listeria spp. were identified as Listeria innocua. According to TVC values and sensory changes, the shelf life of carp portions was determined as 6 days in MAP1, 8 days in MAP2 and 3 days in air.
\end{abstract}

Freshwater fish, food safety, Listeria, Salmonella, shelf life

Fresh fish muscle is a highly perishable product with a very short shelf life, due to the presence of a large amount of water (high $\mathrm{a}_{\mathrm{w}}$ ), a low content of carbohydrate (neutral $\mathrm{pH}$ ), and the presence of native autolytic and microbial proteolytic enzymes. Spoilage of fish results from changes caused by the oxidation of lipids, reactions caused by the activities of the fish's own enzymes, and the metabolic activities of microorganisms (Sivertsvik et al. 2002). Several methods are used to extend the shelf life of fish and fish products. The storage of fish in modified atmospheres has traditionally been used for preservation in package, and in combination with refrigeration has proven to be an effective method for extending the shelf life of fresh fish and fish products (Ruiz-Capillas and Moral 2001; Pantazi et al. 2008). Modified atmosphere packaging (MAP) is the preservation technique. In this technique, the air inside the packaging is replaced by a specific gas or mixture of gases that differ from the composition of air (Cakli et al. 2006). The gaseous atmosphere changes continuously during storage because of respiration of the packed product, biochemical changes, and the slow permeation of gases through the packaging materials (Özogul and Özogul 2006). The three main commercially used gases in modified atmosphere packaging are carbon dioxide $\left(\mathrm{CO}_{2}\right)$, nitrogen $\left(\mathrm{N}_{2}\right)$ and oxygen $\left(\mathrm{O}_{2}\right)$. $\mathrm{CO}_{2}$ is the most important gas used in MAP for fish because of its bacteriostatic and fungistatic properties (Sivertsvik et al. 2002). The bacteriostatic effect of MAP is influenced by the $\mathrm{CO}_{2}$ concentration, the initial bacterial population, the storage temperature and the product being packaged. In food presenting high moisture and/or fat amounts, such as fish, beef and poultry, the excessive absorption of $\mathrm{CO}_{2}$ may lead to a phenomenon known as "packaging collapse". $\mathrm{N}_{2}$ is an insipid and inert gas, showing low solubility in water and lipids. It is used for displacing the oxygen from the packaging, decreasing oxidative rancidness and inhibiting the growth of aerobic microorganisms. Due to its low solubility it is used as

Address for correspondence:

H. Buchtová

Department of Meat Hygiene and Technology

University of Veterinary and Pharmaceutical Sciences Brno

Palackého 1-3, 61242 Brno, Czech Republic
Phone: +420541562742

Fax: +420541321230

E-mail: buchtovah@vfu.cz

http://www.vfu.cz/acta-vet/actavet.htm 
a filling gas preventing possible packaging collapse caused by the accumulation of $\mathrm{CO}_{2}$ (Soccol and Oetterer 2003). Oxygen causes oxidative rancidity in fatty fish, stimulates growth of aerobic bacteria and inhibits growth of strictly anaerobic bacteria (Arashisar et al. 2004).

Fishery products, which are of great importance for human nutrition worldwide and provide clear health benefits, can also act as a source of food-borne pathogens (Herrera et al. 2006). Food poisoning organisms in fish are often divided into two groups: those that are naturally present in the freshwater environment, referred to as indigenous bacteria, and those associated with pollution of the aquatic environment. A third group includes bacteria introduced into fish and fish products during post-harvest handling and processing (González-Rodríguez et al. 2002). The ubiquitous nature of L. monocytogenes and Listeria spp., in conjunction with the use of surface waterways for the discharge of sewage effluents, inevitably results in the presence of these organisms in a wide range of surface water, including lakes, rivers and streams (Sauders and Wiedmann 2007). Nevertheless, the paucity of reports documenting L. monocytogenes in live freshwater fish and shellfish suggests that Listeria spp. cultured from retail products are most likely from post-harvest contamination (Wesley 2007). Listeria spp. and Listeria monocytogenes have been isolated from various species of fish and fish products around the world (Jinneman et al. 2007). The prevalence of $L$. monocytogenes in raw fresh fish has been analysed in many studies and varies from zero to about 30\% (Miettinen and Wirtanen 2005).

Enteric organisms such as Salmonella spp. can enter aquaculture systems from many sources including farm runoff and direct contamination from wild animals, livestock and feed. These bacteria, which are one of the most important causes of human gastrointestinal disease worldwide, are not recognised as part of the normal flora of temperate aquatic environments, and their presence in aquaculture products is related to rearing practices, as well as faulty hygiene practices during post-harvest handling and processing (GonzálezRodríguez et al. 2002).

The aim of the present study was to observe the effect of two different modified atmospheres on the microbial growth rate in fresh chilled carp during storage, with respect to determining its shelf life and surveying the presence of Salmonella spp. and Listeria monocytogenes in common carp (Cyprinus carpio L.).

\section{Materials and Methods}

\section{Carp production and packaging}

In total, 360 samples from 90 fresh common carp were examined in this study and three different atmospheres were used: a) air (control samples), b) experimental MAP1 $\left(70 \% \mathrm{~N}_{2} / 30 \% \mathrm{CO}_{2}\right)$, c) experimental MAP2 (80\% $\mathrm{O}_{2} / 20 \% \mathrm{CO}_{2}$ ).

All the samples of common carp were obtained from the same processing plant and all the carp were treated in the same way. After being killed, scaled and gutted the fish were decapitated and the fishtail trimmed. Each fish was subsequently cut into four portions of approximately the same weight. All the portions of fresh fish were primarily packed in PE bags in the processing plant and chilled to $+4 \pm 0.5^{\circ} \mathrm{C}$. Samples intended for storage in MAP were immediately repacked in polyamide/polyethylene pouches after the transport to the laboratory (Amilen PA/PE 20/60, VF Verpackungen GmbH, Germany) with transmission rate at $23{ }^{\circ} \mathrm{C}: 50 \mathrm{~cm}^{3} / \mathrm{m}^{2} / \mathrm{day} \mathrm{for}$ oxygen, $10 \mathrm{~cm}^{3} / \mathrm{m}^{2} /$ day for nitrogen and $150 \mathrm{~cm}^{3} / \mathrm{m}^{2} /$ day for carbon dioxide. The gas mixtures used for MAP1 $\left(70 \% \mathrm{~N}_{2} / 30 \% \mathrm{CO}_{2}\right)$ and MAP2 $\left(80 \% \mathrm{O}_{2} / 20 \% \mathrm{CO}_{2}\right)$ were provided by a commercial company (Linde Gas a.s., Czech Republic). After packaging the samples were stored at $+4 \pm 0.5^{\circ} \mathrm{C}$ for 10 days.

Microbiological analyses and sensory assessment

Total viable counts (TVC), psychrotrophic viable counts (PVC), coliform bacteria and Escherichia coli were investigated on day 0 (production day) and on days 3, 7 and 10 of the storage period. Microbiological analyses were performed according to the appropriate ISO standards and a sample of 10 grams of tissue was used. After decimal dilution, total viable counts (CSN ISO 4833) and psychrotrophic viable counts (CSN ISO 17412) were determined on Standard Plate Count Agar (Oxoid, Basingstoke, UK), coliform bacteria (CSN ISO 4832) on Violet Red Bile Agar (Oxoid, Basingstoke, UK) and Escherichia coli (CSN ISO 16649-2) on TBX Agar (Merck, Darmstadt, Germany). 
Determination of Salmonella spp. and Listeria spp. was performed on the production day (day 0) and on day 7 of storage. Samples of 25 grams were used for each analysis. Detection of Salmonella spp. was performed according to CSN EN ISO 6579 with cultivation on XLD and Brilliant Green Agar (Oxoid, Basingstoke, UK). After the enrichment procedure carried out according to CN EN ISO $11290-1$, Listeria spp. were determined on Chromocult ${ }^{\mathbb{R}}$ Listeria Selective Agar acc. Ottaviani and Agosti (Merck, Darmstadt, Germany) and PALCAM Agar (Oxoid, Basingstoke, UK). Colonies suspected as Listeria spp. were subsequently confirmed and identified by molecular methods. After DNA isolation, genus-specific identification of isolates was primarily performed using PCR assay (Bubert et al. 1992). Strains confirmed as Listeria spp. were subsequently subjected to speciesspecific identification by multiplex PCR (Huang et al. 2007).

Sensory assessment was provided by three trained laboratory assistants. The general appearance, muscle colour and odour were examined prior to the microbiological analyses.

\section{Statistics}

Statistical analyses of total viable counts, psychrotrophic viable counts and coliform bacteria were performed by a Multisample Median Test (Unistat v.4.1, Unistat Ltd.). The results of microbial counts are expressed as a median with median absolute deviation (MAD). Analysis of Listeria spp. incidence was determined by the MannWhitney U-test (Statistica Cz 7, StatSoft CR s.r.o.).

\section{Results}

In our study, the growth rate of total viable counts, psychrotrophic viable counts and coliform bacteria in portions of fresh common carp during storage at $+4 \pm 0.5^{\circ} \mathrm{C}$ was investigated. Fig. 1 shows total viable counts in portions of common carp stored in air, MAP1 ( $\left.70 \% \mathrm{~N}_{2} / 30 \% \mathrm{CO}_{2}\right)$ and MAP2 $\left(80 \% \mathrm{O}_{2} / 20 \% \mathrm{CO}_{2}\right)$ during 10 days of storage. The initial microbial quality of fish was good, representing numbers of TVC of $10^{4} \mathrm{cfu} / \mathrm{g}$. An increase in the TVC values through the storage period was observed in all types of packaging, with the most remarkable changes occurring in the control samples packaged in air. After 10 days in air packaging, the numbers of TVC reached $12.50 \pm 1.00 \mathrm{log} \mathrm{cfu} / \mathrm{g}$. In MAP1 and MAP2 the inhibition of microbial growth was more intensive during storage when compared with air packaging. The TVC values in MAP1 and MAP2 acquired after 10 days of storage were $7.50 \pm 0.20$ and $7.40 \pm 0.70 \mathrm{log} \mathrm{cfu} / \mathrm{g}$, respectively. Significant differences $(p<0.001)$ in TVC values between MAP1 and control samples and similarly between MAP2 and control samples were determined on storage day 7 and storage day 10 . Nevertheless, no significant differences $(p>0.05)$ were noticed between MAP1 and MAP2 on storage days 7 and 10 .

Fig. 2 shows psychrotrophic viable counts in carp portions during storage. From the initial level of $3.60 \pm 0.30 \mathrm{log} \mathrm{cfu} / \mathrm{g}$, PVC values in air packaging increased gradually up to $11.40 \pm 1.70 \log \mathrm{cfu} / \mathrm{g}$ after 10 days of storage. In MAP1 the growth of psychrotrophic

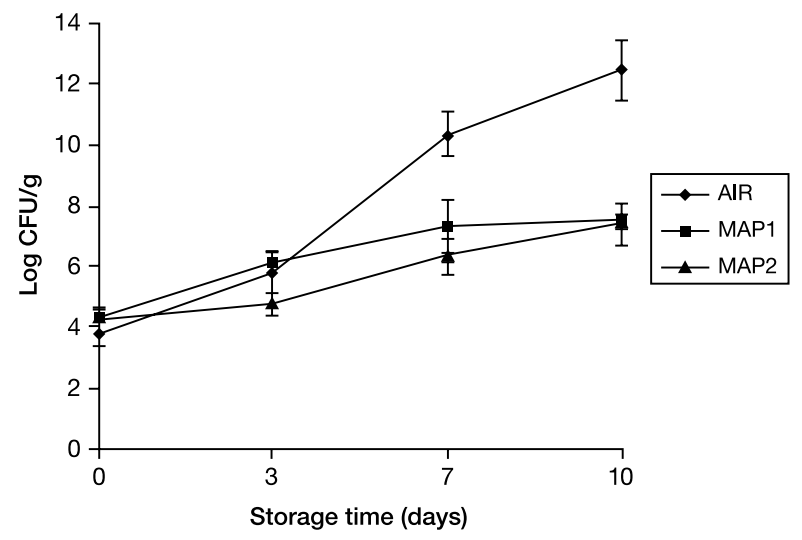

Fig. 1. Changes in total viable counts during storage of carp portions packaged in air, MAP1 and MAP2. 


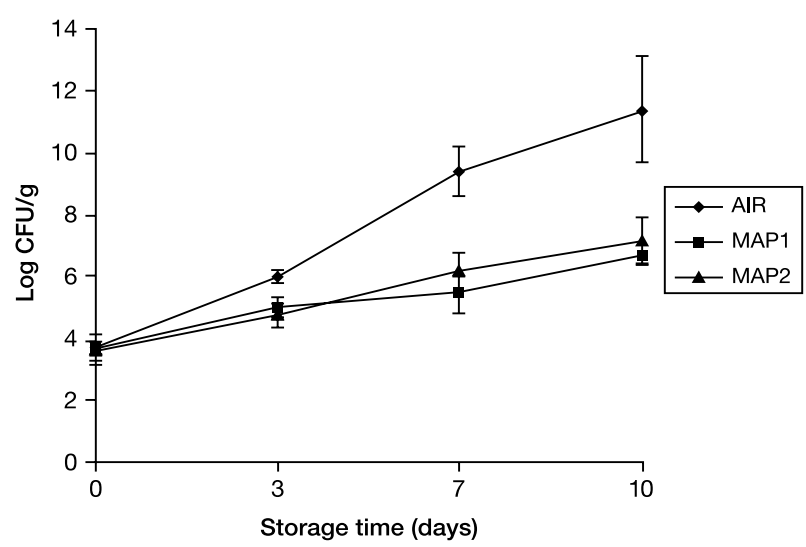

Fig. 2. Changes in psychrotrophic viable counts during storage of carp portions packaged in air, MAP1 and MAP2.

microorganisms was slower, reaching figures of $6.70 \pm 0.30 \mathrm{log} \mathrm{cfu} / \mathrm{g}$ on storage day 10 . PVC values showed significant differences $(p<0.001)$ between MAP1 and air packaging on storage days 7 and 10. The results of psychrotrophic viable counts in MAP2 during the ten days of storage are comparable with those of MAP1. After 10 days storage the numbers of psychrotrophic bacteria reached $7.15 \pm 0.80 \log \mathrm{cfu} / \mathrm{g}$. Significant differences $(p<0.001)$ between PVC values of MAP2 and air packaging were determined on storage day 7 as well as on storage day 10 .

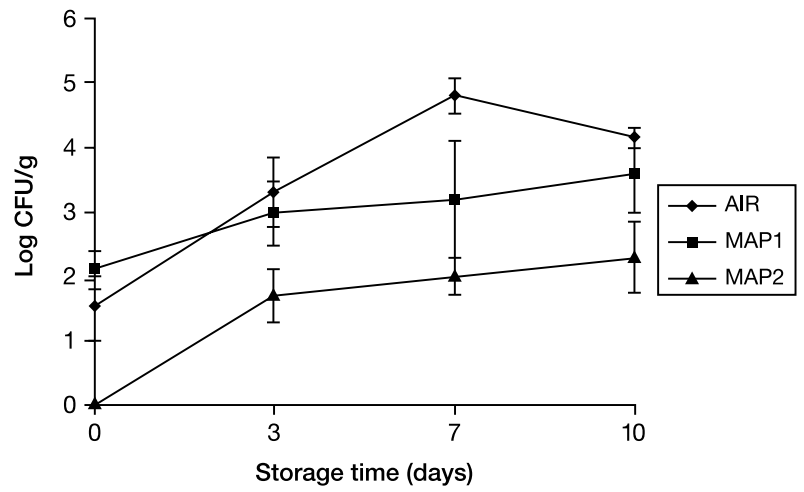

Fig. 3. Changes in coliform bacteria during storage of carp portions packaged in air, MAP1 and MAP2.

Fig. 3 shows numbers of coliform bacteria in carp portions during storage. The contents of coliform bacteria at the beginning of storage varied in all types of packaging: $1.55 \pm$ $0.55 \mathrm{log} \mathrm{cfu} / \mathrm{g}$ in air, $2.10 \pm 0.30 \mathrm{log} \mathrm{cfu} / \mathrm{g}$ in MAP1 and $<1 \log \mathrm{cfu} / \mathrm{g}$ in MAP2. After 7 days storage in air the numbers of coliform bacteria increased to $4.80 \pm 0.25 \mathrm{log} \mathrm{cfu} / \mathrm{g}$, but a decrease in coliform bacteria on day 10 of storage was observed $(4.15 \pm 0.15 \mathrm{log} \mathrm{cfu} / \mathrm{g})$. Although on production day the numbers of coliforms in MAP1 were higher than in air, the growth of bacteria through the storage period was lower, showing significant differences $(p<0.001)$ on storage day $7(3.20 \pm 0.90 \mathrm{log} \mathrm{cfu} / \mathrm{g})$. The low numbers of coliforms detected in MAP2 on production day $(<1 \mathrm{log} \mathrm{cfu} / \mathrm{g})$ reached $2.30 \pm 0.55 \log \mathrm{cfu} / \mathrm{g}$ after 10 days of storage. 
E. coli contamination in all the examined samples during this experiment was $<1 \log$ $\mathrm{cfu} / \mathrm{g}$, except for two air-packaged samples on production day showing 1.3 and $2.3 \mathrm{log}$ $\mathrm{cfu} / \mathrm{g}$ respectively.

Table 1. Incidence of Salmonella spp. and Listeria spp. in carp portions

\begin{tabular}{|c|c|c|c|c|c|}
\hline \multirow{2}{*}{$\begin{array}{c}\text { Type of } \\
\text { packaging }\end{array}$} & \multirow{2}{*}{$\begin{array}{c}\text { No. of } \\
\text { samples } \\
\text { examined }\end{array}$} & \multicolumn{3}{|c|}{ No. of samples positive } \\
\cline { 3 - 6 } & & \multicolumn{2}{|c|}{ Storage day 0 } & \multicolumn{2}{c|}{ Storage day 7 } \\
\cline { 3 - 6 } & 30 & 0 & 15 & 0 & Sisteria spp. \\
\hline Air & 30 & 0 & 20 & 0 & 23 \\
\hline MAP1 & 30 & 0 & 18 & 0 & 13 \\
\hline MAP2 & 90 & 0 & 53 & 0 & 57 \\
\hline Total & & & & & Salmonella spp. \\
\hline
\end{tabular}

Salmonella spp. and Listeria spp. were investigated in samples on production day and after 7 days of storage (Table 1). Salmonella spp. were not detected in any of the examined samples. The number of Listeria spp. positive samples stored in air was lower on production day (15 samples) than after 7 days of storage (23 samples). In MAP1, the numbers of Listeria spp. positive samples were practically the same on storage days 0 and 7 (20 vs. 21), whereas in MAP2 the number of positive samples was lower after 7 days of storage (13 samples) than on production day (18 samples). However, no significant differences $(p>0.05)$ were determined between production day and storage day 7 in any of the atmospheres. All the strains were subsequently identified as Listeria innocua.

\section{Discussion}

Modified atmosphere packaging (MAP) is widely used for extending the shelf life of a wide variety of food, including fish and fish products. The efficiency of MAP in extending the shelf life of fish depends on several factors, such as the fish species, fat content, initial microbial cell load, the gas mixture in MAP and, most importantly, the storage temperature. In our study a significant decrease in the microbial growth rate was observed in MAP1 $\left(30 \% \mathrm{CO}_{2} / 70 \% \mathrm{~N}_{2}\right)$ during storage when compared to air packaging. The effect of various $\mathrm{CO}_{2}$ contents has previously been examined in a number of studies, and delayed microbial growth has been reported e.g. in rainbow trout (Arashisar et al. 2004; Randell et al. 1997), herring (Özogul et al. 2000; Randell et al. 1997), swordfish (Pantazi et al. 2008), chub mackerel (Stamatis and Arkoudelos 2007), sea bass (Poli et al. 2006), sardines (Özogul et al. 2004), salmon (de la Hoz et al. 2000), and cod (Sivertsvik 2007). $\mathrm{CO}_{2}$ is responsible for the bacteriostatic effect in modified atmospheres and its general effects on microorganisms are the intensification of their latest growth stage and a decrease in the growth rate during the logarithmic stage (Farber 1991). However, the CO content in MAP used in this study was low (30\%) when compared to other studies using MAP with $100 \%$ $\mathrm{CO}_{2}$ (Arashisar et al. 2004; Sivertsvik 2007), 60\% $\mathrm{CO}_{2}$ (Cakli et al. 2006; Özogul et al. 2000; Özogul et al. 2004) or 50\% $\mathrm{CO}_{2}$ (Ravi Sankar et al. 2008), a positive effect on reduced microbial growth was observed.

Although the application of MAP with $\mathrm{O}_{2}$ is questionable in fish because of possible lipid oxidation, a modified atmosphere with an elevated $\mathrm{O}_{2}$ level (MAP2 $80 \% \mathrm{O}_{2} / 20 \%$ $\mathrm{CO}_{2}$ ) was shown to be efficient in our study in terms of its inhibitory effects on the TVC and PVC. This effect on TVC and PVC was evident as early as storage day 3, although significant differences $(p<0.01)$ were detected after 7 and 10 days of storage. There is little information on the effect of MAP with elevated $\mathrm{O}_{2}$ level on bacterial growth retardation in the literature. Based on microbiological, chemical and sensory analyses, Sivertsvik 
(2007) reported that the optimised modified atmosphere for the packaging of filleted cod is $63 \% \mathrm{O}_{2} / 37 \% \mathrm{CO}_{2}$. Ravi Sankar et al. (2008) and Lalitha et al. (2005) examined the effect of various modified atmospheres on pearl spot, including a $60 \% \mathrm{O}_{2} / 40 \% \mathrm{CO}_{2}$ atmosphere. During storage they detected a microbial growth decrease resulting in a longer shelf life when compared to air packaging.

Salmonella spp. are not recognised as part of the normal flora of the temperate aquatic environment and their presence in aquaculture products is related to rearing practices, as well as to faulty hygiene practices during post-harvest handling and processing (GonzálezRodríguez et al. 2002). In this study, Salmonella spp. were not detected in any of the examined samples. Similarly to our results, Salmonella spp. were not detected in farmed rainbow trout and salmon (González-Rodríguez et al. 2002) or in various kinds of marine fish (Davies et al. 2001; Herrera et al. 2006).

Although Listeria spp. were detected in this study, no L. monocytogenes was identified. All the strains were confirmed as L. innocua. Listeria monocytogenes has been isolated worldwide, with various prevalence ranges from a variety of fish (Ben Embarek 1994; Kwiatek 2004; Medrala et al. 2003; Miettinen and Wirtanen 2005; Herrera et al. 2006; Jinneman et al. 2007), but as in other raw foods, fishery products more frequently contain L. innocua than L. monocytogenes. Since both species share ecological niches, the presence of $L$. innocua is considered an indicator of possible contamination with L. monocytogenes (González-Rodríguez et al. 2002). Because of their psychrotrophic nature, Listeria spp. are able to survive and grow in fish at refrigerating temperatures even when stored under modified atmosphere packaging. Our results showed that MAP with an elevated $\mathrm{O}_{2}$ level (80\%) was more effective in decreasing Listeria spp. positive samples during storage when compared to air packaging and MAP1, which can be explained by the microaerophilic and facultative anaerobic nature of Listeria spp.

No sensory changes of portions in air were detected on storage day 3. After 7 days of storage, however, changes in colour and odour were observed with an elevated amount of surface slime. These changes were even more intensive on storage day 10 . In both MAP used in this study, sensory changes were only detected after 10 days of storage, accompanied by moderate colour changes, a fishy odour and a layer of surface slime.

The shelf life of carp portions was determined by total viable counts $\left(10^{6}-10^{7}\right.$ microorganisms/g was considered the TVC limit of acceptability) and sensory changes, indicating approximately 3 days for portions in air, 6 days for MAP1, and 8 days for MAP2.

\section{Vplyv modifikovanej atmosféry na mikrobiologické vlastnosti kapra obyčajného (Cyprinus carpio L.)}

Ciel'om štúdie bolo porovnat' mieru rastu celkového počtu mikroorganizmov (CPM), počtu psychrotrofných mikroorganizmov (PPM), koliformných baktérií a E. coli v porciách kapra obyčajného (Cyprinus carpio L.) balených do dvoch rôznych modifikovaných atmosfér (experimentálna MAP1: $70 \% \mathrm{~N}_{2} / 30 \% \mathrm{CO}_{2}$; experimentálna MAP2: $80 \%$ $\mathrm{O}_{2} / 20 \% \mathrm{CO}_{2}$ ) a vzduchu (kontrolné vzorky) počas skladovania pri $+4 \pm 0,5^{\circ} \mathrm{C}$ a určit' ich trvanlivost'. V rámci štúdie bola detekovaná prítomnost' patogénnych mikroorganizmov (Salmonella spp. a Listeria monocytogenes). Celkovo bolo vyšetrených 360 vzoriek z 90 kusov čerstvých rýb. Laboratórne vyšetrenia boli vykonávané na 0. (deň produkcie), 3., 7. a 10. deň skladovania. V porovnaní s kontrolnými vzorkami, boli počty CPM a PPM vo vzorkách balených do modifikovaných atmosfér (MAP) významne nižšie $(p<0,001)$ na 7. a 10. deň skladovania, zatial' čo počty koliformných baktérií boli nižšie len na 7. deň skladovania. Počty $E$. coli vo vzorkách boli počas skladovania všeobecne nízke, na úrovni $<1 \log \mathrm{cfu} / \mathrm{g}$. Prítomnost' Salmonella spp. a Listeria monocytogenes nebola preukázaná v žiadnej z vyšetrovaných vzoriek. Všetky kmene Listeria spp. boli identifikované ako 
Listeria innocua. Na základe CPM a senzorických zmien bola trvanlivost' porcií kapra balených v MAP1 stanovená na 6 dní, v MAP2 na 8 dní a vo vzduchu na 3 dni.

\section{Acknowledgement}

Financial support for this study was provided by the Ministry of Education, Youth and Sports of the Czech Republic (Research Plan MSM6215712402) and IGA 40/2007/FVHE.

\section{References}

Arashisar Ş, Hisar O, Kaya M, Yanik T 2004: Effects of modified atmosphere and vacuum packaging on microbiological and chemical properties of rainbow trout (Oncorhynchus mykiss) fillets. Int J Food Microbiol 97: 209-214

Ben Embarek PK 1994: Presence, detection and growth of Listeria monocytogenes in seafoods: a review. Int J Food Microbiol 23: 17-34

Bubert A, Koulet S, Goebel W 1992: The homologous and heterologous regions within the iap gene allow genusand species-specific identification of Listeria spp. by polymerase chain reaction. Appl Environ Microbiol 58: 2625-2632

Cakli S, Kilinc B, Dincer T, Tolasa S 2006: Comparison of the shelf lifes of map and vacuum packed hot smoked rainbow trout (Oncorhynchus mykiss). Eur Food Res Technol 224: 19-26

Davies AR, Capell CH, Jehanno D, Nychas GJE, Kirby RM 2001: Incidence of foodborne pathogens on European fish. Food Control 12: 67-71

De la Hoz L, López-Gálvez DE, Fernández M, Hierro E, Ordóñez JA 2000: Use of carbon dioxide enriched atmospheres in the refrigerated storage $\left(2{ }^{\circ} \mathrm{C}\right)$ of salmon (Salmo salar) steaks. Eur Food Res Technol 210: $179-188$

Farber JM 1991: Microbiological aspects of modified-atmosphere packaging technology - a review. J Food Prot 54: $58-70$

González-Rodríguez MN, Sanz JJ, Santos JA, Otero A, García-López ML 2002: Foodborne pathogenic bacteria in prepackaged fresh retail portion of farmed rainbow trout and salmon stored at $3{ }^{\circ} \mathrm{C}$. Int $\mathrm{J}$ Food Microbiol 76: $135-141$

Herrera FC, Santos JA, Otero A, García-López ML 2006: Occurrence of foodborne pathogenic bacteria in retail prepackaged portions of marine fish in Spain. J Appl Microbiol 100: 527-536

Huang B, Eglezos S, Heron BA, Smith H, Graham T, Bates J, Savill J 2007: Comparison of multiplex PCR with conventional biochemical methods for the identification of Listeria spp. isolates from food and clinical samples in Queensland, Australia. J Food Prot 70: 1874-1880

Jinneman KC, Wekell MM, Eklund MW 2007: Incidence and behaviour of Listeria monocytogenes in fish and seafood. In: Ryser ET, Marth EH (Eds.), Listeria, Listeriosis, and Food Safety. CRC Press, New York, pp. $617-653$

Kwiatek K 2004: Occurrence of Listeria monocytogenes in selected food of animal origin. Bull Vet Inst Pulawy 48: $269-272$

Lalitha KV, Sonaji ER, Manju S, Jose L, Gopal TKS, Ravisankar CN 2005: Microbiological and biochemical changes in pearl spot (Etroplus suratensis Bloch) stored under modified atmospheres. J Appl Microbiol 99: $1222-1228$

Mędrala D, Dąbrowski W, Czekajło-Kołodziej U, Daczkowska-Kozon E, Koronkiewicz A, Augustynowicz E, Manzano M 2003: Persistence of Listeria monocytogenes strains isolated from products in a Polish fishprocessing plant over a 1-year period. Food Microbiol 20: 715-724

Miettinen H, Wirtanen G 2005: Prevalence and location of Listeria monocytogenes in farmed rainbow trout. Int J Food Microbiol 104: 135-143

Özogul F, Özogul Y 2006: Biogenic amine content and biogenic amine quality indices of sardines (Sardina pilchardus) stored in modified atmosphere packaging and vacuum packaging. Food Chem 99: 574-578

Özogul F, Polat A, Özogul Y 2004: The effect of modified atmosphere packaging and vacuum packaging on chemical, sensory and microbiological changes of sardines (Sardina pilchardus). Food Chem 85: 49-57

Özogul F, Taylor KDA, Quantick P, Özogul Y 2000: Chemical, microbiological and sensory evaluation of Atlantic herring (Clupea harengus) stored in ice, modified atmosphere and vacuum pack. Food Chem 7: 267-273

Pantazi D, Papavergou A, Pournis N, Kontominas MG, Savvaidis IN 2008: Shelf-life of chilled fresh Mediterranean swordfish (Xiphias gladius) stored under various packaging conditions: Microbiological, biochemical and sensory attributes. Food Microbiol 25: 136-143

Poli BM, Messini A, Parisi G, Scappini F, Vigiani V, Giorgi G, Vincenzini M 2006: Sensory, physical, chemical and microbiological changes in European sea bass (Dicentrarchus labrax) fillets packed under modified atmosphere/air or prepared from whole fish stored in ice. Int J Food Sci Technol 41: 444-454

Randell K, Hattula T, Ahvenainen R 1997: Effect of packaging method on the quality of Rainbow trout and Baltic herring fillets. LWT-Food Sci Technol 30: 56-61

Ravi Sankar CN, Lalitha KV, Jose L, Manju S, Gopal TKS 2008: Effect of packaging atmosphere on the microbial attributes of pearlspot (Etroplus suratensis Bloch) stored at $0-2{ }^{\circ} \mathrm{C}$. Food Microbiol 25: $518-528$ 
Ruiz-Capillas C, Moral A 2001: Chilled bulk storage of gutted hake (Merluccius merluccius L.) in $\mathrm{CO}_{2}$ and $\mathrm{O}_{2}$ enriched controlled atmospheres. Food Chem 74: 317-325

Sauders BD, Wiedmann M 2007: Ecology of Listeria species and L. monocytogenes in the natural environment. In: Ryser ET, Marth EH (Eds.), Listeria, Listeriosis, and Food Safety. CRC Press, New York, pp. 21-53

Sivertsvik M 2007: The optimized modified atmosphere for packaging of pre-rigor filleted farmed cod (Gadus morhua) is $63 \mathrm{ml} / 100 \mathrm{ml}$ oxygen and $37 \mathrm{ml} / 100 \mathrm{ml}$ carbon dioxide. LWT-Food Sci Technol 40: 430-438

Sivertsvik M, Jeksrud WK, Rosnes JT 2002: A review of modified atmosphere packaging of fish and fishery products - significance of microbial growth, activities and safety. Int J Food Sci Technol 37: 107-127

Soccol MCH, Oetterer M 2003: Use of modified atmosphere in seafood preservation. Braz Arch Biol Technol 46: $569-580$

Stamatis N, Arkoudelos J 2007: Quality assessment of Scomber colias japonicus under modified atmosphere and vacuum packaging. Food Control 18: 292-300

Wesley IV 2007: Listeriosis in animals. In: Ryser ET, Marth EH (Eds.), Listeria, Listeriosis, and Food Safety. CRC Press, New York, pp. 55-84 